\title{
High-quality forage can replace concentrate when cows enter the deposition phase without negative consequences for milk production
}

\author{
L. Hymøller, ${ }^{* 1}$ L. Alstrup, ${ }^{*}$ M. K. Larsen,† P. Lund, ${ }^{*}$ and M. R. Weisbjerg* \\ *Department of Animal Science, and \\ †Department of Food Science, AU Foulum, Aarhus University, Blichers Allé 20, PO Box 50, DK-8830 Tjele, Denmark
}

\begin{abstract}
Mobilization and deposition in cows are different strategies of metabolism; hence, the aim was to study the possibility of reducing the crude protein (CP) supply during deposition to limit the use of protein supplements and minimize the environmental impact. A total of 61 Jersey and 107 Holstein cows were assigned to 4 mixed rations in a $2 \times 2$ factorial design with 2 concentrate to forage ratios (CFR) and 2 CP levels: high CFR (40:60) and recommended CP [16\% of dry matter (DM); HCFR-RP], high CFR (40:60) and low CP (14\% of DM; HCFR-LP), low CFR (30:70) and recommended CP (16\% of DM; LCFR-RP), and low CFR (30:70) and low CP (14\% of DM; LCFR-LP), where RP met the Danish recommendations. Cows were fed concentrate in an automatic milking unit. After calving, cows were fed HCFR-RP until entering deposition, defined as 11 $\mathrm{kg}$ (Jersey) or $15 \mathrm{~kg}$ (Holstein) of weight gain from the lowest weight after calving. Subsequently, cows either remained on HCFR-RP or changed to one of the other mixed rations. Comparing strategies during wk 9 to 30 of lactation showed higher dry matter intake (DMI) of mixed ration on HCFR compared with LCFR and on RP compared with LP. The DMI of the concentrate was higher on LCFR than on HCFR and higher on LP than on RP, resulting in overall higher DMI on HCFR and RP than on LCFR and LP. Crude protein intakes were higher on RP than on LP and starch intakes were higher on HCFR than on LCFR. Intakes of neutral detergent fiber tended to be higher on LCFR than on HCFR. Intakes of net energy for lactation were affected by CFR and CP level, with a higher intake on HCFR and RP than on LCFR and LP. No interactions were found between CFR and CP level for any feed intake variables. Yields of milk and energy-corrected milk were higher on RP than on LP, with no difference in yield persistency after the ration change. Milk composition did not differ among strategies but the protein to fat
\end{abstract}

Received November 19, 2013.

Accepted March 13, 2014.

${ }^{1}$ Corresponding author: Lone.Hymoller@agrsci.dk ratio was higher on HCFR than on LCFR and tended to be lower on RP than on LP. Differences in fatty acid composition were small, and de novo synthesis was high (>60\%). Energy efficiency was higher on LCFR than on HCFR and no interaction with breed or parity was found. The N efficiency was higher on LP than RP, but with an interaction with breed due to lower $\mathrm{N}$ efficiency in Jersey than Holstein cows on HCFR-RP but higher $\mathrm{N}$ efficiency in Jersey than Holstein on LCFR-LP. In dairy production, concentrate in the mixed ration can be substituted with high-quality forage during deposition without negative effects on milk yield and composition when a sufficient CP level is ensured.

Key words: forage ratio, protein level, dairy cow, environment

\section{INTRODUCTION}

Research in dairy cattle nutrition has recently focused mainly on developing tools for controlling individual feed allocation to dairy cows, for example, to support their individual requirements for energy and nutrients according to stage of lactation. However, rising prices of feedstuffs, particularly ingredients for concentrate mixtures, have strengthened interest in substituting energy-rich cereal grains with high-quality forage and optimizing the use of protein-rich supplements. Furthermore, optimizing the protein supply for dairy cattle can reduce the environmental impact by reducing the loss of $\mathrm{N}$ to the environment (Oldham, 1984), which has become a major focal point in dairy production (Børsting et al., 2003).

The utilization of energy and protein in ruminants is intimately linked. Even though dietary protein is utilized both for amino acids and for microbial protein synthesis in the rumen (Oldham, 1984; Broderick, 2003), the efficiency of protein utilization is dependent on the energy supply. This is because rations high in energy support microbial protein synthesis in the rumen, thereby increasing the supply of microbial protein for utilization by the ruminant (Oldham, 1984; Broderick, 2003). Oversupplying energy is uneconomical and could cause problems for ruminants through a 
compromised rumen environment with decreased $\mathrm{pH}$ and fiber degradability from excessive starch intake, ultimately resulting in reduced production (Broderick, 2003). Oversupplying protein induces a physiological strain on the animal, which has to handle an excess of $\mathrm{N}$ in the body (Fenderson and Bergen, 1976), and it increases the environmental impact of dairy production through increased $\mathrm{N}$ excretion from the animal (Broderick, 2003).

Energy and protein demands in dairy cows change significantly with stage of lactation. In early lactation, the typical mobilization of body reserves shows that energy and nutrients are allocated to milk production. During the subsequent deposition period, energy and nutrients are increasingly allocated to other life functions, such as reproduction and weight gain (Bossen et al., 2009). Hence, the mobilization and deposition periods represent 2 distinctly different strategies of allocating energy and nutrients within the body (Knegsel et al., 2007; Bjerre-Harpøth et al., 2012).

Recent experiments have shown that it is possible to reduce the energy supply of individual dairy cows when they change from mobilization to deposition without detrimental effects on milk yield and animal health (Bossen and Weisbjerg, 2009; Bossen at al., 2009). However, the possibility of also reducing the protein supply has not been established under modern production conditions. Hence, the aim of the present study was to establish whether decreasing the concentrate to forage ratio (CFR) of the mixed ration (MR) from 40:60 to 30:70 could be accompanied by a decrease in CP supply from approximately 16 to $14 \%$ of $\mathrm{DM}$ for lactating dairy cows in deposition, without negatively affecting milk production.

\section{MATERIALS AND METHODS}

\section{Animals and Experimental Design}

All animal experiments complied with the Danish Ministry of Justice Law No. 726 (September 9th, 1993) concerning experiments with animals and care of experimental animals. A total of 61 Danish Jersey and 107 Danish Holstein cows, were, within breed, allocated to different treatment strategies according to parity (primiparous and multiparous) and expected calving date. Cows were allocated to 4 different feeding strategies in a $2 \times 2$ factorial design with $2 \mathrm{CFR}$ and $2 \mathrm{CP}$ levels in the MR. The 4 different treatment rations were as follows: high CFR (40:60) and recommended CP level (16\% of DM; HCFR-RP), high CFR (40:60) and low CP level (14\% of DM; HCFR-LP), low CFR (30:70) and recommended CP level (16\% of DM; LCFR-RP), and low CFR (30:70) and low CP level (14\% of DM;
LCFR-LP). Starting weights for the cows were 598.9 $\pm 54.1 \mathrm{~kg}$ (Holstein primiparous), $664.4 \pm 69.1 \mathrm{~kg}$ (Holstein multiparous), $429.8 \pm 33.8 \mathrm{~kg}$ (Jersey primiparous), and $470.1 \pm 41.6 \mathrm{~kg}$ (Jersey multiparous). All cows were fed the HCFR-RP ration commencing on d 1 after calving and until the individual cows had gained $11 \mathrm{~kg}$ (Jersey) or $15 \mathrm{~kg}$ (Holstein), respectively, from the lowest recorded weight after calving (prechange). The desired weight gains were chosen based on previous studies showing that these weight gains were consistent with cows having entered deposition (Bossen and Weisbjerg, 2009; Bossen et al., 2009). Subsequently, the cows either remained on the HCFR-RP ration or changed to 1 of the other 3 rations until wk 30 of lactation (post-change). No cows were allowed to change rations earlier than wk 8 after calving regardless of their weight gain within that period of time. A total of 40 cows changed ration in wk 8 of lactation (i.e., as soon as it was allowed).

\section{Housing and Management}

The experiment was carried out at the Danish Cattle Research Centre (Tjele, Denmark) between January 2010 and May 2011. Cows were kept in a loose-housing system with slatted floors and stalls with mattresses. A free cow traffic system was applied, where cows were not restricted in access to mangers, stalls, or the automatic milking system (AMS) from DeLaval AB (Tumba, Sweden) at any point in time. Within the dairy unit, cows were organized in 3 groups (AMS groups), 1 with Jersey cows and 2 with Holstein cows, giving rise to approximately twice as many Holstein as Jersey in the study. Each group had access to an automatic milking unit (AMU) equipped with a device for automatic measurement of milk yield and milk sampling for chemical analysis. Additionally the AMU was equipped with a device for feeding a commercial concentrate mixture (CCM) and weighing of CCM refusals at the end of each cow visit. Below each AMU, a platform scale from Danvaegt (Hinnerup, Denmark) was installed for automatic weighing of cows at every milking. Body condition score was assessed every second week as described by Ferguson et al. (1994). The RIC system (Insentec, Marknesse, the Netherlands) was used for automatic recording of MR intake in mangers mounted on scales and with automatic cow registration by electronic ear tag. Dry matter contents of roughages were determined weekly and rations adjusted accordingly. When cows changed rations, they changed to a different set of mangers but remained in the same AMS group. Cows that remained on the HCFR-RP ration changed to a different set of mangers to even out any effect of changing the mangers from 
Table 1. Planned composition, concentrate to forage ratio, $\mathrm{CP}, \mathrm{AA}$ absorbed in the small intestine, and rumen protein balance of mixed rations ${ }^{1}$

\begin{tabular}{|c|c|c|c|c|}
\hline \multirow[b]{2}{*}{ Item } & \multicolumn{2}{|c|}{ HCFR } & \multicolumn{2}{|c|}{ LCFR } \\
\hline & $\mathrm{RP}$ & LP & $\mathrm{RP}$ & LP \\
\hline Concentrate to forage ratio & $40: 60$ & $40: 60$ & $30: 70$ & $30: 70$ \\
\hline \multicolumn{5}{|l|}{ Composition, $\%$ of DM } \\
\hline Barley & 9.0 & 11.6 & 3.5 & 6.0 \\
\hline Canola meal, $4 \%$ fat & 7.0 & 3.0 & 7.0 & 3.0 \\
\hline Soybean meal, $48 \% \mathrm{CP}$ & 2.0 & 0.0 & 2.0 & 0.0 \\
\hline Beet pulp, dried & 7.5 & 10.6 & 1.5 & 4.5 \\
\hline Grass clover silage & 30.0 & 30.1 & 36.0 & 36.2 \\
\hline Corn silage & 31.0 & 31.1 & 36.5 & 36.7 \\
\hline Concentrate $^{2}$ & 12.5 & 12.6 & 12.5 & 12.6 \\
\hline Vitamin and mineral mix $^{3}$ & 1.0 & 1.0 & 1.0 & 1.0 \\
\hline $\mathrm{CP}, \%$ of $\mathrm{DM}$ & 15.9 & 13.9 & 16.2 & 14.2 \\
\hline $\mathrm{AAT}_{20}, \%$ of DM & 9.38 & 8.89 & 9.19 & 8.70 \\
\hline $\mathrm{PBV}_{20}, 5 \%$ of DM & 1.35 & -0.15 & 1.90 & 0.40 \\
\hline \multicolumn{5}{|c|}{$\begin{array}{l}{ }^{1} \mathrm{HCFR}=\text { high concentrate to forage ratio }(40: 60) ; \mathrm{LCFR}=\text { low concentrate to forage ratio }(30: 70) ; \mathrm{RP}= \\
\text { recommended } \mathrm{CP} \text { level }(16 \%) ; \mathrm{LP}=\text { low } \mathrm{CP} \text { level }(14 \%) .\end{array}$} \\
\hline \multicolumn{5}{|c|}{$\begin{array}{l}{ }^{2} \text { Commercial concentrate fed in the automatic milking unit consisting of canola meal } 23 \% \text {, sugar beet pulp, } \\
\text { dried } 17 \% \text {, barley } 13 \% \text {, wheat } 12 \% \text {, oats } 10 \% \text {, sunflower cake, partly dehulled } 7 \% \text {, artificially dried grass, } \\
\text { pelleted } 5 \% \text {, wheat bran } 5 \% \text {, soybean meal, dehulled and toasted } 4 \% \text {, sugar beet molasses } 2 \% \text {, vitamins and } \\
\text { minerals } 2 \% \text {. }\end{array}$} \\
\hline \multicolumn{5}{|c|}{$\begin{array}{l}{ }^{3} \text { Vitamin A } 566,000 \mathrm{IU} / \mathrm{kg} \text { of DM; vitamin } \mathrm{D}_{3} 102,000 \mathrm{IU} / \mathrm{kg} \text { of DM; vitamin E } 3.388 \mathrm{IU} / \mathrm{kg} \text { of DM; Ca } 290 \\
\mathrm{~g} / \mathrm{kg} \text { of DM; } \mathrm{Mg} 62 \mathrm{~g} / \mathrm{kg} \text { of DM; S } 39 \mathrm{~g} / \mathrm{kg} \text { of DM; Mn } 4 \mathrm{mg} / \mathrm{kg} \text { of DM; Zn } 7 \mathrm{mg} / \mathrm{kg} \text { of DM; Cu } 1.385 \mathrm{mg} / \mathrm{kg} \text {; } \\
\text { Co } 31 \mathrm{mg} / \mathrm{kg} \text { of DM; Se } 28 \mathrm{mg} / \mathrm{kg} \text { of DM; I } 198 \mathrm{mg} / \mathrm{kg} \text { of DM. Monocalcium phosphate and sodium chloride } \\
\text { were added to balance diets. }\end{array}$} \\
\hline \multicolumn{5}{|c|}{${ }^{4}$ Amino acids absorbed in the small intestine at $20 \mathrm{~kg}$ of DMI, as calculated in NorFor (2011). } \\
\hline
\end{tabular}

which cows ate. The technical facilities and procedures at the Danish Cattle Research Centre are described in more detail by Bossen et al. (2009) and Bossen and Weisbjerg (2009).

\section{Rations and Feeding}

The different rations are listed in Table 1 . The CFR of the MR was 40:60 in the HCFR rations and 30:70 in the LCFR rations on a DM basis. Forage consisted of $50 \%$ grass clover silage and $50 \%$ corn silage, and the low CFR were obtained by replacing barley and sugar beet pulp with the forage mixture. The RP and LP rations were formulated to contain $\mathrm{CP}$ levels of approximately $16 \%$ or $14 \%$ of $\mathrm{DM}$, respectively. The $\mathrm{RP}$ rations met the Danish recommendations for MP $\left(\mathrm{AAT}_{20} ; \mathrm{AA}\right.$ absorbed in the small intestine at $20 \mathrm{~kg}$ of DMI) and rumen protein balance $\left(\mathrm{PBV}_{20}\right.$; protein balance in the rumen at $20 \mathrm{~kg}$ of $\mathrm{DMI})$, whereas the $\mathrm{LP}$ rations, as planned, were deficient in $\mathrm{PBV}_{20}$ (NorFor, 2011). The different CP levels were obtained by including soybean meal and increasing the canola meal content. Cows were fed $1 \mathrm{~kg}$ of the CCM in the AMU on d 1 after calving. Subsequently, the daily allowance was increased by $150 \mathrm{~g} / \mathrm{d}$ until an allowance of $3 \mathrm{~kg} / \mathrm{d}$ was reached on d 14 after calving. Nine weeks before expected calving, the CCM allowance was gradually decreased by $500 \mathrm{~g} / \mathrm{d}$ until an allowance of $0 \mathrm{~kg} / \mathrm{d}$ was reached.

\section{Laboratory Analyses}

Feed. Dry matter in feed was determined by drying in a forced-air oven at $60^{\circ} \mathrm{C}$ for $48 \mathrm{~h}$. Ash was analyzed after heating to $525^{\circ} \mathrm{C}$ (AOAC International, 2000). Crude protein in feedstuffs was calculated as $6.25 \times$ total N according to the Dumas principle (Hansen, 1989). Crude fat was analyzed by extraction with petroleum ether after hydrolysis in $\mathrm{HCl}$ (Stoldt, 1952). Sugar was analyzed by the Luff-Schoorl method modified from Schoorl (1929). Starch was analyzed by an enzymatic calorimetric technique (Knudsen et al., 1987). The NDF content (reported as ash free) was determined by neutral detergent extraction (Mertens, 2002) using sodium sulfite and heat-stable amylase on a Fibertec M6 System (Foss Analytical, Hillerød, Denmark). Fatty acids were analyzed by acid-catalyzed methylation followed by GC using an HP 6890 GC equipped with a flame-ionization detector (Agilent Technologies, Santa Clara, CA) and a Restek 2560 column (100 m, 0.25 $\mu \mathrm{m}$ i.d., $0.2 \mu \mathrm{m}$ film thickness; Restek, Bellefonte, PA; Larsen et al., 2012b). Values for net energy content were calculated as Scandinavian Feed Units (SFU) and presented as megajoules of $\mathrm{NE}_{\mathrm{L}}$ using the fixed conver- 
Table 2. Chemical composition of individual feedstuffs

\begin{tabular}{|c|c|c|c|c|c|c|c|}
\hline Item & \multicolumn{7}{|c|}{ Feedstuff } \\
\hline \multicolumn{8}{|l|}{ Nutrient, $\%$ of DM } \\
\hline Ash & 1.9 & 7.9 & 7.1 & 7.1 & 9.9 & 3.3 & 7.3 \\
\hline $\mathrm{CP}$ & 11.7 & 40.1 & 52.4 & 8.8 & 17.0 & 8.9 & 21.3 \\
\hline Crude fat & 2.9 & 4.7 & 2.9 & 1.1 & 3.3 & 2.3 & 3.6 \\
\hline $\mathrm{NDF}$ & 17.1 & 25.6 & 11.2 & 38.4 & 37.7 & 39.2 & 25.5 \\
\hline $\begin{array}{l}\mathrm{NE}_{\mathrm{L}}, \mathrm{MJ} / \mathrm{kg} \text { of } \mathrm{DM} \\
\mathrm{FA}, \% \text { of } \mathrm{DM}\end{array}$ & 8.9 & 8.8 & 11.0 & 7.9 & 7.0 & 7.0 & 8.2 \\
\hline C16 & 0.41 & 0.35 & 0.53 & 0.31 & 0.40 & 0.36 & 0.67 \\
\hline C18:0 & 0.09 & 0.07 & 0.03 & 0.01 & 0.04 & 0.05 & 0.07 \\
\hline C18:1 & 0.40 & 2.11 & 0.22 & 0.14 & 0.05 & 0.27 & 1.14 \\
\hline C18:2 & 1.20 & 1.01 & 1.12 & 0.32 & 0.34 & 0.72 & 1.09 \\
\hline
\end{tabular}

${ }^{1}$ Commercial concentrate fed in the automatic milking unit; composition given in Table 1.

sion coefficient 7.89 $\mathrm{MJ}$ of $\mathrm{NE}_{\mathrm{L}} / \mathrm{SFU}$ (Weisbjerg and Hvelplund, 1993; Bossen et al., 2009). The chemical composition of individual feedstuffs is listed in Table 2.

Milk. Milk samples from all milkings were collected during $48 \mathrm{~h}$ every week and analyzed for contents of fat, protein, and lactose at Eurofins Steins Laboratories (Holstebro, Denmark) on a Milkoscan 4000 infrared analyzer (Foss Electric, Hillerød, Denmark). Milk samples for assessing urea levels in the milk were collected on 12 occasions during the study and analyzed using flow injection. Urease was added to dilute milk samples; after the reaction, a strong alkali solution was added and the developing ammonia dialyzed. Changes in $\mathrm{pH}$ of the passing, aqueous phase were monitored via a spectrophotometer $\mathrm{pH}$ indicator, as described in the application provided by the manufacturer (Foss Tecator AB, Höganäs, Sweden). For analysis of milk FA composition, individual samples from cows in lactation wk 14 to 36 were taken on 1 occasion. Milk fat was isolated by centrifugation and analyzed for FA composition (Larsen et al., 2012b).

\section{Statistics and Calculations}

A total of 168 cows were used in the final statistical calculations, distributed among breeds and treatments, as shown in Table 3. Before calculations, 25 cows were completely omitted from the raw data set: 2 due to severely fluctuating feed intakes between weeks, 8 because they changed rations later than wk 29, 1 due to several missing milk samples, and 14 because more than $10 \%$ of their DMI was from rations other than the assigned treatment. Sixteen cows had single weeks omitted from the data set because of isolated cases of disease, mainly due to digital dermatitis, but no difference in incidence was observed among treatments. By wk 12 after calving, $78.3 \%$ of all cows had gained sufficient weight to change rations; by wk 24 after calving, this percentage had increased to $98.9 \%$.

Changes in BW and BCS and persistence in ECM yield were estimated by linear regression in the REG procedure of SAS (SAS Institute Inc., Cary, NC) postchange in individual cows. The effect of treatments on

Table 3. Number of cows used for statistical analysis within breed, feeding strategy, and parity ${ }^{1}$

\begin{tabular}{|c|c|c|c|c|c|c|c|c|c|}
\hline \multirow{2}{*}{ Parity } & \multicolumn{4}{|c|}{ Holstein } & \multicolumn{4}{|c|}{ Jersey } & \multirow{2}{*}{ Total } \\
\hline & \multicolumn{2}{|c|}{ HCFR } & \multicolumn{2}{|c|}{ LCFR } & \multicolumn{2}{|c|}{ HCFR } & \multicolumn{2}{|c|}{ LCFR } & \\
\hline Primiparous & 8 & 10 & 15 & 11 & 6 & 7 & 5 & 4 & 66 \\
\hline Multiparous & 15 & 17 & 14 & 17 & 9 & 10 & 11 & 9 & 102 \\
\hline Total & 23 & 27 & 29 & 28 & 15 & 17 & 16 & 13 & 168 \\
\hline
\end{tabular}


slopes of the regressions, milk urea content, and changing week was tested in the MIXED models procedure of SAS (SAS Institute Inc.) using the model

$$
\begin{aligned}
\mathrm{Y}_{i j k l m}= & \mu+\alpha_{i}+\beta_{j}+(\alpha \beta)_{i j}+\delta_{k}+(\alpha \beta \delta)_{i j k} \\
& +\lambda_{l}+(\alpha \beta \lambda)_{i j l}+E_{i j k l m}+\varepsilon_{i j k l m},
\end{aligned}
$$

where $\mathrm{Y}_{i j k l m}$ is the dependent variable; $\mu$ is the overall mean; $\alpha_{i}$ is the fixed effect of the CFR $i$ (HCFR, LCFR); $\beta_{j}$ is the fixed effect of the CP level $j(\mathrm{RP}, \mathrm{LP})$; $(\alpha \beta)_{i j}$ is the effect of the interaction between CFR $i$ and CP level $j ; \delta_{k}$ is the fixed effect of parity $k$ (primiparous, multiparous); $(\alpha \beta \delta)_{i j k}$ is the interaction between CFR $i$, CP level $j$, and parity $k ; \lambda_{l}$ is the fixed effect of breed $l$ (Holstein, Jersey); $(\alpha \beta \lambda)_{i j l}$ is the interaction between CFR $i$, CP level $j$, and breed $l ; E_{i j k l m}$ is the random effect of animal $m(1,2, \ldots, 168)$; and $\varepsilon_{i j k l}$ is the random residual error. Random effects were assumed normally distributed with mean value 0 and constant variance $E_{i j k l m} \sim N\left(0, \sigma_{E}^{2}\right)$ and $\varepsilon_{i j k l m} \sim N\left(0, \sigma^{2}\right)$.

Energy efficiency was calculated as ECM $(\mathrm{kg} / \mathrm{d}) / \mathrm{NE}_{\mathrm{L}}$ $(\mathrm{MJ} / \mathrm{d})$ and $\mathrm{N}$ efficiency as [milk protein $(\mathrm{kg} / \mathrm{d}) / 6.38] /$ [CP uptake $(\mathrm{kg} / \mathrm{d}) / 6.25]$ (Børsting et al., 2003). The ANOVA on uptake of feed and nutrients and production variables was performed using the MIXED models procedure of SAS (SAS Institute Inc.). Covariates (COV) of the different response variables for individual cows were calculated from the mean of results obtained during wk 1 to 8 after calving. The following model was applied to data obtained during wk 9 to 30 of lactation in Holstein and Jersey cows:

$$
\begin{aligned}
& \mathrm{Y}_{i j k l m n}=\mu+\mathrm{COV}+\alpha_{i}+\beta_{j}+(\alpha \beta)_{i j}+\gamma_{k}+\delta_{l} \\
& +(\alpha \beta \delta)_{i j l}+\lambda_{m}+(\alpha \beta \lambda)_{i j m}+E_{i j k l m n}+\varepsilon_{i j k l m n},
\end{aligned}
$$

where $\mathrm{Y}_{i j k l m n}$ is the dependent variable; $\mu$ is the overall mean; COV is the calculated covariate; $\alpha_{i}$ is the fixed effect of CFR $i$ (HCFR, LCFR); $\beta_{j}$ is the fixed effect of CP level $j(\mathrm{RP}, \mathrm{LP}) ;(\alpha \beta)_{i j}$ is the effect of the interaction between CFR $i$ and CP level $j ; \gamma_{k}$ is the fixed effect of week number $k(9,10, \ldots, 30) ; \delta_{l}$ is the fixed effect of parity $l$ (primiparous, multiparous); $(\alpha \beta \delta)_{i j l}$ is the interaction between CFR $i$, CP level $j$, and parity $l ; \lambda_{m}$ is the fixed effect of breed $m$ (Holstein, Jersey); $(\alpha \beta \lambda)_{i j m}$ is the interaction between CFR $i$, CP level $j$, and breed $m ; E_{i j k l m n}$ is the random effect of animal $n$ (1, $2, \ldots, 168)$; and $\varepsilon_{i j k l m n}$ is the random residual error. Random effects were assumed normally distributed with mean value 0 and constant variance $E_{i j k l m n} \sim N\left(0, \sigma_{E}^{2}\right)$ and $\varepsilon_{i j k l m n} \sim N\left(0, \sigma^{2}\right)$. To account for the covariance structure of the repeated measures during consecutive weeks within individual cows, the repeated statement for the MIXED procedure in SAS was used (Littell et al., 2006). The covariance structures were modeled using compound symmetry or autoregressive first-order covariance structures. The effects on milk FA composition were tested using the model

$$
\mathrm{Y}_{i j k}=\mu+\alpha_{i}+\beta_{j}+(\alpha \beta)_{i j}+\gamma_{k}+\delta_{l}+(\alpha \beta \gamma)_{i j k}+\varepsilon_{i j k},
$$

where $Y_{i j k}$ is the dependent variable; $\mu$ is the overall mean; $\alpha_{i}$ is the fixed effect of CFR $i$ (HCFR, LCFR); $\beta_{j}$ is the fixed effect of CP level $j(\mathrm{RP}, \mathrm{LP}) ;(\alpha \beta)_{i j}$ is the effect of the interaction between CFR $i$ and CP level $j$; $\gamma_{k}$ is the fixed effect of breed $k$ (Holstein, Jersey); $(\alpha \beta \gamma)_{i j k}$ is the interaction between CFR $i$, CP level $j$, and breed $k$; and $\varepsilon_{i j k}$ is the random residual error. Random effects were assumed normally distributed with mean value 0 and constant variance $\varepsilon_{i j k} \sim N\left(0, \sigma^{2}\right)$.

The above-mentioned models considered the 4 treatments (HCFR-RP, HCFR-LP, LCFR-RP, and LCFRLP) as feeding strategies from wk 9 to wk 30. To study the acute effects of the ration change, linear regression from wk 9 to 30, excluding the change week, was performed in the MIXED procedure of SAS (SAS Institute Inc.). Regressions included the relevant dependent variables and their $\mathrm{COV}$, week, parity, and breed as class variables together with a fixed dummy variable $\left(\mathrm{D}_{1}, \mathrm{D}_{2}, \mathrm{D}_{3}, \mathrm{D}_{4}\right)$ each representing 1 of the 4 treatments (HCFR-RP, HCFR-LP, LCFR-RP, and LCFR-LP) and assigned the value 0 pre-change and the value 1 post-change. Interactions between regression variables, parity, and breed were also included.

Results were presented as LSM \pm SEM and differences considered statistically significant when $P \leq 0.05$ and as tendencies when $0.05<P<0.10$.

\section{RESULTS}

\section{Intake of Feed, Nutrients, and Energy}

Holstein cows, on average, reached the ration change 2 wk earlier than Jersey but no differences were found between treatment groups within breeds (Table 4). When comparing the different treatments as feeding strategies during wk 9 to 30 of lactation, the MR DMI was higher on HCFR $(16.7 \pm 0.2 \mathrm{~kg} / \mathrm{d})$ than on LCFR $(15.8 \pm 0.2 \mathrm{~kg} / \mathrm{d} ; P \leq 0.001)$ and higher on RP $(16.6$ $\pm 0.2 \mathrm{~kg} / \mathrm{d})$ than on $\mathrm{LP}(15.8 \pm 0.2 \mathrm{~kg} / \mathrm{d} ; P \leq 0.001)$ (Table 4). The CCM DMI was higher on LCFR $(2.3 \pm$ $0.03 \mathrm{~kg} / \mathrm{d})$ than on HCFR $(2.2 \pm 0.03 \mathrm{~kg} / \mathrm{d} ; P \leq 0.001)$ and higher on LP $(2.3 \pm 0.003 \mathrm{~kg} / \mathrm{d})$ than on RP $(2.2 \pm$ $0.03 \mathrm{~kg} / \mathrm{d} ; P \leq 0.01)$. This resulted in an overall higher 
DMI on HCFR $(18.8 \pm 0.2 \mathrm{~kg} / \mathrm{d})$ and RP $(18.8 \pm 0.2$ $\mathrm{kg} / \mathrm{d})$ than on LCFR $(18.1 \pm 0.2 \mathrm{~kg} / \mathrm{d} ; P \leq 0.01)$ and $\mathrm{LP}(18.1 \pm 0.2 \mathrm{~kg} / \mathrm{d} ; P \leq 0.01)$. The planned CP levels of the rations were similar to the achieved levels (Table 1 and Table 4). As expected, the intake of $\mathrm{CP}$ was higher on RP $(2.99 \pm 0.03 \mathrm{~kg} / \mathrm{d})$ than $\mathrm{LP}(2.59 \pm 0.03$ $\mathrm{kg} / \mathrm{d} ; P \leq 0.001)$ and the intake of starch was higher on HCFR $(3.03 \pm 0.05 \mathrm{~kg} / \mathrm{d})$ than on LCFR $(2.69 \pm$ $0.05 \mathrm{~kg} / \mathrm{d} ; P \leq 0.001)$. The intake of NDF tended to be higher at RP $(6.26 \pm 0.06 \mathrm{~kg} / \mathrm{d})$ than on LP $(6.10 \pm$ $0.06 \mathrm{~kg} / \mathrm{d} ; P \leq 0.05)$. The intake of $\mathrm{NE}_{\mathrm{L}}$ was affected by both $\mathrm{CFR}$ and $\mathrm{CP}$ level, with a higher $\mathrm{NE}_{\mathrm{L}}$ intake on HCFR $(7.49 \pm 0.01 \mathrm{MJ} / \mathrm{kg}$ of DM) and RP $(7.46 \pm$ $0.01 \mathrm{MJ} / \mathrm{kg}$ of DM) than on LCFR $(7.38 \pm 0.01 \mathrm{MJ} /$ $\mathrm{kg}$ of DM; $P \leq 0.001)$ and $\mathrm{LP}(7.41 \pm 0.01 \mathrm{MJ} / \mathrm{kg}$ of $\mathrm{DM} ; P \leq 0.001)$. No interactions were found between $\mathrm{CFR}$ and $\mathrm{CP}$ level for any intake variables. Interaction between CFR, CP level, and breed was found in CCM intake $(P=0.08)$, due to Jersey cows eating more CCM than Holstein cows on LCFR-LP but less than Holstein on all $\mathrm{RP}$ rations. Also, for $\mathrm{CP}$ intake, an interaction was found between CFR, CP level, and breed because Jersey decreased their CP intake less than Holstein on the LCFR-LP strategy (Table 4). Differences between primiparous and multiparous cows were encountered, but no interactions were found between CFR, CP level, and parity in any feed and nutrient intake variables (data not presented).

\section{Milk Yield and Composition}

Similar ECM yields occurred between HCFR (27.9 $\pm 0.3 \mathrm{~kg} / \mathrm{d})$ and LCFR $(27.7 \pm 0.3 \mathrm{~kg} / \mathrm{d} ; P=0.59)$, whereas ECM yields were higher on RP $(28.6 \pm 0.3$ $\mathrm{kg} / \mathrm{d})$ than on LP $(27.0 \pm 0.3 \mathrm{~kg} / \mathrm{d} ; P \leq 0.001)$ but no difference was observed among strategies in milking persistency after the feed change. Milk composition did not differ among strategies but we did detect an effect of CFR on the protein to fat ratio of the milk, which was higher on HCFR than LCFR. The CP level tended to affect the protein to fat ratio of the milk due to a higher ratio on RP than on LP rations. In general, even though differences between parity and breed existed, no interactions were found between CFR, level of $\mathrm{CP}$, and breed or parity for any milk yield or milk composition variables. The milk urea content was lower on LP and HCFR than on RP and LCFR (Table 5).

\section{Production Efficiency}

Energy efficiency was affected by CFR due to a higher efficiency on LCFR than on HCFR; no interaction with breed or parity was found. The CP level affected N efficiency, which was higher on LP than on RP. However,

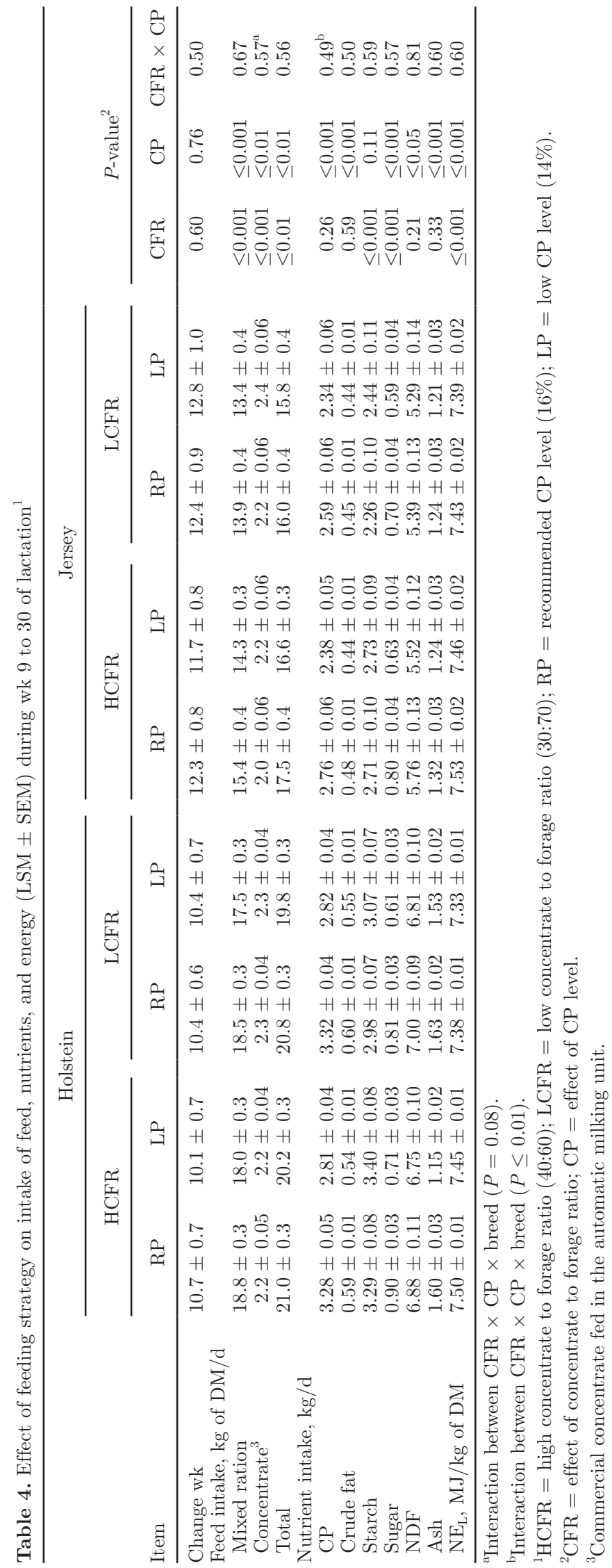


Table 5. Effect of feeding strategy on milk yield, composition, persistency, production efficiency, milking frequency, BW, and BCS (LSM \pm SEM) during wk 9 to 30 of lactation (unless stated otherwise) ${ }^{1}$

\begin{tabular}{|c|c|c|c|c|c|c|c|c|c|c|c|}
\hline \multirow[b]{3}{*}{ Item } & \multicolumn{4}{|c|}{ Holstein } & \multicolumn{4}{|c|}{ Jersey } & & & \\
\hline & \multicolumn{2}{|c|}{ HCFR } & \multicolumn{2}{|c|}{ LCFR } & \multicolumn{2}{|c|}{ HCFR } & \multicolumn{2}{|c|}{ LCFR } & \multicolumn{3}{|c|}{$P$-value ${ }^{2}$} \\
\hline & $\mathrm{RP}$ & LP & $\mathrm{RP}$ & LP & $\mathrm{RP}$ & LP & $\mathrm{RP}$ & LP & CFR & $\mathrm{CP}$ & $\begin{array}{l}\mathrm{CFR} \times \\
\mathrm{CP}\end{array}$ \\
\hline \multicolumn{12}{|l|}{ Yield, $\mathrm{kg} / \mathrm{d}$} \\
\hline Milk & $30.7 \pm 0.6$ & $28.2 \pm 0.5$ & $30.0 \pm 0.5$ & $27.9 \pm 0.5$ & $19.3 \pm 0.7$ & $18.4 \pm 0.6$ & $18.7 \pm 0.7$ & $18.6 \pm 0.7$ & 0.45 & $\leq 0.01$ & 0.46 \\
\hline $\mathrm{ECM}^{3}$ & $31.8 \pm 0.5$ & $29.3 \pm 0.5$ & $31.2 \pm 0.4$ & $29.3 \pm 0.6$ & $25.9 \pm 0.6$ & $24.6 \pm 0.6$ & $25.4 \pm 0.6$ & $24.9 \pm 0.6$ & 0.59 & $\leq 0.001$ & 0.35 \\
\hline $\begin{array}{l}\operatorname{ECM}(\Delta),{ }^{3,4} \mathrm{~kg} / \mathrm{wk} \\
\text { Composition. \% }\end{array}$ & \multicolumn{10}{|c|}{ Composition, $\%$} & 0.66 \\
\hline Fat & $4.22 \pm 0.09$ & $4.32 \pm 0.08$ & $4.31 \pm 0.08$ & $4.42 \pm 0.08$ & $6.09 \pm 0.10$ & $6.03 \pm 0.10$ & $6.17 \pm 0.10$ & $6.04 \pm 0.11$ & 0.28 & 0.94 & 0.84 \\
\hline Protein & $3.65 \pm 0.04$ & $3.62 \pm 0.04$ & $3.63 \pm 0.04$ & $3.60 \pm 0.04$ & $4.58 \pm 0.05$ & $4.54 \pm 0.05$ & $4.52 \pm 0.05$ & $4.48 \pm 0.06$ & 0.24 & 0.29 & 0.94 \\
\hline Lactose & $4.91 \pm 0.02$ & $4.92 \pm 0.02$ & $4.90 \pm 0.01$ & $4.90 \pm 0.02$ & $4.76 \pm 0.02$ & $4.80 \pm 0.02$ & $4.80 \pm 0.02$ & $4.82 \pm 0.02$ & 0.56 & 0.22 & 0.64 \\
\hline Protein to fat ratio & $0.88 \pm 0.01$ & $0.85 \pm 0.01$ & $0.85 \pm 0.01$ & $0.83 \pm 0.08$ & $0.76 \pm 0.01$ & $0.76 \pm 0.01$ & $0.74 \pm 0.01$ & $0.74 \pm 0.01$ & $\leq 0.01$ & $\leq 0.05$ & 0.61 \\
\hline Urea, $\mathrm{mmol} / \mathrm{L}$ & $3.07 \pm 0.10$ & $2.54 \pm 0.04$ & $3.44 \pm 0.08$ & $2.83 \pm 0.09$ & $3.35 \pm 0.12$ & $2.91 \pm 0.11$ & $3.42 \pm 0.12$ & $2.97 \pm 0.12$ & $<0.01$ & $<0.001$ & 0.77 \\
\hline \multicolumn{12}{|l|}{ Production efficiency } \\
\hline Energy efficiency ${ }^{5}$ & $0.202 \pm 0.004$ & $0.195 \pm 0.003$ & $0.204 \pm 0.003$ & $0.201 \pm 0.003$ & $0.197 \pm 0.004$ & $0.200 \pm 0.004$ & $0.214 \pm 0.004$ & $0.216 \pm 0.005$ & $\leq 0.001$ & 0.64 & $0.77^{\mathrm{a}}$ \\
\hline $\mathrm{N}$ efficiency ${ }^{6}$ & $0.33 \pm 0.01$ & $0.35 \pm 0.005$ & $0.32 \pm 0.005$ & $0.34 \pm 0.005$ & $0.31 \pm 0.01$ & $0.35 \pm 0.01$ & $0.32 \pm 0.01$ & $0.36 \pm 0.01$ & 0.81 & $<0.001$ & $0.79^{\mathrm{b}}$ \\
\hline Milking frequency, $\mathrm{d}^{-1}$ & $2.2 \pm 0.1$ & $2.1 \pm 0.1$ & $2.2 \pm 0.05$ & $2.2 \pm 0.1$ & $2.2 \pm 0.1$ & $2.2 \pm 0.1$ & $2.2 \pm 0.1$ & $2.3 \pm 0.1$ & 0.14 & 0.41 & 0.68 \\
\hline \multicolumn{12}{|l|}{ Selected FA, } \\
\hline C4-C14 & $33.63 \pm 0.52$ & $32.19 \pm 0.45$ & $32.46 \pm 0.61$ & $32.68 \pm 0.64$ & $30.93 \pm 0.35$ & $32.27 \pm 0.75$ & $30.83 \pm 0.92$ & $32.20 \pm 0.62$ & 0.69 & 0.50 & 0.44 \\
\hline $\mathrm{C} 13$ & $0.18 \pm 0.007$ & $0.17 \pm 0.014$ & $0.14 \pm 0.007$ & $0.14 \pm 0.005$ & $0.21 \pm 0.007$ & $0.20 \pm 0.010$ & $0.20 \pm 0.016$ & $0.17 \pm 0.013$ & $\leq 0.01$ & 0.16 & 0.57 \\
\hline $\mathrm{C} 15$ & $1.57 \pm 0.04$ & $1.52 \pm 0.08$ & $1.39 \pm 0.04$ & $1.40 \pm 0.03$ & $1.79 \pm 0.04$ & $1.69 \pm 0.07$ & $1.67 \pm 0.05$ & $1.53 \pm 0.06$ & $<0.01$ & 0.15 & 0.92 \\
\hline $\mathrm{C} 16$ & $35.31 \pm 0.74$ & $35.75 \pm 0.58$ & $34.12 \pm 0.73$ & $34.33 \pm 0.58$ & $40.35 \pm 0.61$ & $38.57 \pm 1.10$ & $38.59 \pm 1.38$ & $38.37 \pm 1.03$ & 0.10 & 0.62 & 0.62 \\
\hline C18:0 & $7.12 \pm 0.30$ & $6.79 \pm 0.19$ & $7.81 \pm 0.26$ & $7.77 \pm 0.32$ & $8.08 \pm 0.25$ & $8.08 \pm 0.27$ & $8.62 \pm 0.28$ & $8.16 \pm 0.21$ & $<0.05$ & 0.40 & 0.88 \\
\hline C18:1 cis-9 & $14.81 \pm 0.41$ & $15.75 \pm 0.60$ & $16.49 \pm 0.56$ & $16.24 \pm 0.53$ & $11.89 \pm 0.38$ & $12.21 \pm 0.42$ & $13.22 \pm 0.38$ & $12.89 \pm 0.30$ & $<0.05$ & 0.72 & 0.34 \\
\hline C18:2n-6 & $1.65 \pm 0.06$ & $1.84 \pm 0.09$ & $1.62 \pm 0.04$ & $1.60 \pm 0.05$ & $1.40 \pm 0.05$ & $1.57 \pm 0.07$ & $1.36 \pm 0.06$ & $1.35 \pm 0.04$ & $\leq 0.05$ & 0.13 & 0.07 \\
\hline $\mathrm{BW}(\Delta), \mathrm{kg} / \mathrm{wk}$ & $1.8 \pm 0.4$ & $1.5 \pm 0.4$ & $2.0 \pm 0.4$ & $1.5 \pm 0.4$ & $2.1 \pm 0.5$ & $1.1 \pm 0.5$ & $1.8 \pm 0.5$ & $1.6 \pm 0.6$ & 0.70 & 0.14 & 0.59 \\
\hline $\operatorname{BCS}(\Delta), \mathrm{wk}^{-1}$ & $0.003 \pm 0.007$ & $0.004 \pm 0.006$ & $0.01 \pm 0.005$ & $0.01 \pm 0.006$ & $0.007 \pm 0.008$ & $0.002 \pm 0.008$ & $0.01 \pm 0.008$ & $0.006 \pm 0.009$ & 0.30 & 0.69 & 0.99 \\
\hline \\
\hline \multicolumn{12}{|c|}{${ }^{\mathrm{b}}$ Interaction between $\mathrm{CFR} \times \mathrm{CP} \times$ breed $(P \leq 0.05)$} \\
\hline \multicolumn{12}{|c|}{${ }^{1} \mathrm{HCFR}=$ high concentrate to forage ratio $(40: 60) ; \mathrm{LCFR}=$ low concentrate to forage ratio $(30: 70) ; \mathrm{RP}=$ recommended $\mathrm{CP}$ level $(16 \%) ; \mathrm{LP}=$ low $\mathrm{CP}$ level $(14 \%)$. } \\
\hline \multicolumn{12}{|c|}{${ }^{2} \mathrm{CFR}=$ effect of concentrate to forage ratio; $\mathrm{CP}=$ effect of $\mathrm{CP}$ level. } \\
\hline \multicolumn{12}{|c|}{${ }^{3} \mathrm{ECM}(3.140 \mathrm{MJ} / \mathrm{kg})$ calculated as described by Sjaunja et al. (1991). } \\
\hline \multicolumn{12}{|c|}{${ }^{4}$ Weekly change in ECM yield after the individual ration change. } \\
\hline \multicolumn{12}{|c|}{${ }^{5}$ Energy efficiency $=\mathrm{kg}$ of ECM/MJ of $\mathrm{NE}_{\mathrm{L}}$. } \\
\hline${ }^{6} \mathrm{~N}$ efficiency $=[$ milk pro & $\operatorname{tein}(\mathrm{kg} / \mathrm{d}) / 6.38$ & 8]/[protein up & $(\mathrm{kg} / \mathrm{d}) / 6.2$ & ting & & & & & & & \\
\hline & & & & & & & & & & & \\
\hline & & & & & & & & & & & \\
\hline & & & & & & & & & & & \\
\hline
\end{tabular}


we did detect an interaction with breed due to a lower $\mathrm{N}$ efficiency in Jersey than Holstein on the HCFR-RP ration but a higher $\mathrm{N}$ efficiency on the LCFR-LP ration in Jersey than in Holstein $(P \leq 0.05$; Table 5$)$. Milking frequencies were similar among treatments (Table 5).

\section{FA Content of Milk}

The effect of feeding strategy on milk FA composition was limited to CFR, resulting in a lower content of C18:0 $(P \leq 0.05)$ and $\mathrm{C} 18: 1$ cis-9 $(P \leq 0.05)$; a higher content of $\mathrm{C} 13(P \leq 0.01), \mathrm{C} 15(P \leq 0.01)$, and $\mathrm{C} 18: 2$ n-6 $(P \leq 0.05)$; and a tendency to a higher content of C16 $(P=0.10)$ in HCFR than in LCFR. No effects of CP level were observed (Table 5).

\section{$B W$ and $B C S$}

After the feed change, BW increased as shown in Table 5, unaffected by CFR or CP level and with no interactions between $\mathrm{CFR}, \mathrm{CP}$ level, and breed $(P=$ $0.67)$ or parity $(P=0.89)$. The BCS changed as shown in Table 5 and again we found no effect of CFR or CP level and no interactions between CFR, CP level, and breed $(P=0.71)$ or parity $(P=0.92)$.

\section{Acute Effects of Ration Change}

When comparing the acute day-to-day effects of ration change in individual cows, DMI declined for all cows when changing to the LP ration, whereas only Jersey cows responded negatively to changing to the LCFR ration with the RP level. All feed changes resulted in declining ECM yields except those in Jerseys on RP rations. The milk fat content increased in Holsteins changing to the LCFR-LP ration and in all Jerseys except those that remained on the HCFR-RP ration. The milk protein content declined in Holsteins changing to the LCFR-LP ration and in Jerseys changing to both LCFR rations, whereas it increased in Jerseys changing to the HCFR-LP ration. This resulted in declining protein to fat ratios in all cows except those that remained on the HCFR-RP rations. Energy efficiency declined in Holsteins changing to the HCFRLP ration and in Jerseys changing to LCFR rations. The $\mathrm{N}$ efficiency increased when Holstein and Jersey cows changed to LP rations but declined in Holstein cows when they changed to the LCFR-RP ration and in Jersey cows that remained on the HCFR-RP ration (Table 6). Changes in variables directly related to the ration change showed no interaction with changing week. Hence, the effect of the ration change was the same regardless of which week in lactation that it took place. Ration change week differed between breeds $(P$ $\leq 0.001)$.

\section{DISCUSSION}

In the present study, we found a significant effect of parity in various feed and nutrient intake and milk production variables because, as expected, DMI and milk yields were higher for multiparous cows than for primiparous cows. However, responses were similar in primiparous and multiparous cows, leading to no interactions between parity and treatments. Likewise, in the study by Bossen et al. (2009), no difference between feeding strategies (early or late reduction of energy levels according to weight gain) was found in primiparous or multiparous cows, probably because milk yield variables were directly correlated to feed and nutrient intake variables within parity. Earlier studies, however, indicated that primiparous cows respond to a reduction in the energy level of the ration by reducing their milk yield, whereas multiparous cows respond by reducing their BW (Spahr et al., 1993).

The DMI was higher on HCFR and RP rations than on LCFR and LP rations, indicating that the feed intake capacity of the cows was so low that the concentrate in the HCFR ration could not be substituted entirely by the forage of the LCFR ration. This is likely related to the digestibility of the forage used, as the substitution rate between highly digestible corn silage and concentrate is usually high when sufficient $\mathrm{CP}$ is supplied to dairy cows (Faverdin et al., 1991; Hymøller et al., 2014). This was further supported by the higher voluntary CCM intake of cows on the LCFR and LP rations than on the HCFR and RP rations, which indicated that cows were motivated for higher CCM intake on the LCFR and LP rations, as shown by others under AMS housing conditions (Madsen et al., 2010).

Yields of milk and ECM were higher on RP rations than on LP rations, because MP was limiting due to a low rumen protein balance $\left(\mathrm{PBV}_{20}\right)$ of the LP rations (Table 1). We observed no additional effect of the CFR of the rations, as supported by the findings of Bossen and Weisbjerg (2009). Milk composition, on the other hand, did not differ among rations. This is in agreement with the findings of Nielsen et al. (2003), who compared conventional (17\% of DM) and low (11\% of DM) CP rations for dairy cows and found that the low $\mathrm{CP}$ ration decreased milk, fat, and protein yields compared with the conventional $\mathrm{CP}$ ration but that the concentrations of fat and protein in the milk were unaffected by the CP level of the rations. In a study involving 74 primiparous Holstein cows by MacLeod et al. (1983), the milk yield and protein and 
lactose contents of the milk increased when the concentrate ratio of corn- and alfalfa-based mixed rations increased from 20 to $65 \%$. Simultaneously, milk fat content declined with increasing concentrate ratios, as seen by others (Larsen et al., 2012b). The lack of effect of the CFR of the rations on milk yield and composition in the present study may be related to the digestibility of the forage in the rations (Larsen et al., 2012b). In dairy goats, Dønnem et al. (2011) showed that the marginal ECM yield response to an increased energy intake was higher when the energy intake was increased by increasing the digestibility of the forage rather than by increasing the concentrate intake, and Randby et al. (2012) showed that dairy cows increased their ECM yield when fed highly digestible grass silage of early harvest compared with less digestible grass silage of later harvest with different levels of concentrate supplementation.

The protein to fat ratio of the milk was higher on the HCFR rations than on the LCFR rations and tended to be higher on the RP rations than on the LP rations. This indicates a lower microbial protein synthesis in the rumen due to an inadequate energy supply (NorFor, 2011) and a higher mobilization of body reserves in cows on the LCFR and LP rations. Milk urea contents were lower on LP and HCFR rations than on RP and LCFR rations. In dairy sheep, Cannas et al. (1998) found that milk urea increased with increasing CP levels of the feed but they found no effect of the energy level of the feed. In cattle, Spek et al. (2013) found, in a summary of the literature, that milk urea was affected by several factors besides ration $\mathrm{CP}$ concentration. Generally, it seems that low energy and high CP intake increase the milk urea content, whereas high energy and low CP intake decrease it (Oltner and Wiktorsson, 1983; Broderick, 2003; Nielsen et al., 2003). However, the urea content of the milk also seems to be affected by the ratio between energy and $\mathrm{CP}$ in the feed, regardless of the actual level of $\mathrm{CP}$ and energy in the feed (Oltner and Wiktorsson, 1983).

The observed differences in milk FA composition depending on the CFR indicate higher microbial synthesis (C13 and C15; Harfoot and Hazlewood, 1997) and decreased hydrogenation (C18:2 n-6) in the rumen on the HCFR rations, but it should be noted that differences were small. Likewise, the decrease in C18:0 and C18:1 cis-9, in combination with the tendency to an increase in C16, indicated a higher de novo synthesis. In general, milk FA composition was characterized by a high content of de novo synthesized FA, including C16, and low content of C18 FA derived from feed; results were similar to those previously reported after feeding mixed rations without fat supplements (Weisbjerg et al., 2008; Larsen et al., 2012a). 
The recovery of FA from feed can be calculated as the ratio between the daily output in milk per day and the daily intake from feed (Larsen et al., 2012a). When these calculations were performed on average data from the current study, the recovery of C18 FA (sum of all isomers) ranged from 1.0 to 1.1 for different treatments for both breeds, and the recovery of C16 FA (C16:0 and $\mathrm{C} 16: 1)$ ranged from 5.5 to 5.8 for Holsteins and from 6.6 to 7.1 for Jerseys. These results demonstrate that the input and output of C18 FA were balanced, whereas the major part ( 80 to $85 \%$ ) of the C16 FA in milk was derived from de novo synthesis. In total, more than $60 \%$ of the milk fat was derived from de novo synthesis, thus the influence of feed FA content on milk FA composition was limited.

When looking at production efficiency with respect to energy and $\mathrm{N}$ utilization, energy efficiency was higher on LCFR than on HCFR, and N efficiency was higher on LP than on RP; however, we found an interaction with breed, probably because the effect of LP was more pronounced in Jersey, resulting in higher $\mathrm{N}$ efficiency in Jersey than in Holstein on LP rations. Also, the later ration change in Jersey compared with Holstein could have been responsible for the interaction with breed, as this resulted in less post-change time for Jersey than for Holstein. Hence, on a total 9- to 30-wk basis, Jersey cows would then have experienced less difference among strategies than would Holstein cows. On a similar note, MacLeod et al. (1983) found increasing energy efficiencies, when correcting for intake of digestible energy, as the concentrate ratio of the rations declined from 65 to $20 \%$. In the present study, Jersey cows had a lower than expected total NDF intake on the LCFR-LP ration compared with the other rations, due to an increased CCM intake in the AMU on the LP rations, which might have affected the final result. In contrast, Broderick (2003) found that increasing the energy content by reducing the NDF concentration of the ration from 36 to $28 \%$ of DM increased both the energy and $\mathrm{N}$ efficiency of dairy cows, but at the same time they found that increasing the CP level from 15.1 to $18.4 \%$ of DM drastically reduced energy and $\mathrm{N}$ efficiencies. Likely, the very high CP level applied in their study affected the outcome. Nielsen et al. (2003) also found reduced N efficiency when feeding high CP concentrates compared with low CP concentrates to grazing cows. However, they showed that high-yielding cows and cows in early lactation were more sensitive to reduced CP levels than cows in later stages of lactation. Hence, to reduce the $\mathrm{CP}$ allowance of dairy cows, and thereby reduce the $\mathrm{N}$ load on the environment, individual concentrate allocation must be applied.

The findings of Bossen and Weisbjerg (2009) indicate that cows in early lactation should be fed highly concentrated rations to increase peak yield. However, live weight or energy balance of the cows should be monitored in real time, to avoid having cows enter deposition by gaining large amounts of BW too early in the lactation. The present study used BW as an objective parameter to describe energy balance, recognizing that measuring $\mathrm{BW}$ does not take into account changes in body composition. Today's technology does allow for incorporation of changes in body composition as a proxy for energy balance on the individual cow level (Thorup et al., 2013), although the challenge is to utilize this knowledge to manage ration energy concentrations. The most practical way is probably to have a designated group for fresh cows, where they remain until they enter deposition. Another possibility is to manage ration energy concentration by the use of automatic concentrate feeders; however, this would induce use of more separately fed concentrate with the potential risk of health problems.

\section{CONCLUSIONS}

In dairy production, concentrate in the mixed ration can be substituted with high-quality forage when cows have entered the deposition period without affecting milk yield and composition. However, cows respond negatively to a simultaneous reduction in the CP level of the mixed ration.

\section{ACKNOWLEDGMENTS}

The staff at the Danish Cattle Research Centre (Tjele, Denmark) is acknowledged for their skilled and enthusiastic cooperation in this project. The Ministry of Food, Agriculture and Fisheries of Denmark, The Danish AgriFish Agency (Copenhagen; GUDP grant), and The Knowledge Center for Agriculture | Cattle (Skejby, Denmark) are acknowledged for financial support.

\section{REFERENCES}

AOAC International. 2000. Official Methods of Analysis. 17th ed. AOAC International, Washington, DC.

Bjerre-Harpøth, V., N. C. Friggens, V. M. Thorup, T. Larsen, B. M. Damgaard, K. L. Ingvartsen, and K. M. Moyes. 2012. Metabolic and production profiles of dairy cows in response to decreased nutrient density to increase physiological imbalance at different stages of lactation. J. Dairy Sci. 95:2362-2380.

Børsting, C. F., T. Kristensen, L. Misciattelli, T. Hvelplund, and M. R. Weisbjerg. 2003. Reducing nitrogen surplus from dairy farms: Effects of feeding and management. Livest. Prod. Sci. 83:165-178.

Bossen, D., and M. R. Weisbjerg. 2009. Allocation of feed based on individual cow live weight changes II: Effect on milk production. Livest. Sci. 126:273-285.

Bossen, D., M. R. Weisbjerg, L. Munksgaard, and S. Højsgaard. 2009. Allocation of feed based on individual dairy cow live weight changes. I: Feed intake and live weight changes during lactation. Livest. Sci. 126:252-272. 
Broderick, G. A. 2003. Effects of varying dietary protein and energy levels on the production of lactating dairy cows. J. Dairy Sci. 86:1370-1381.

Cannas, A., A. Pes, R. Mancuso, B. Vodret, and A. Nudda. 1998. Effect of dietary energy and protein concentration on the concentration of milk urea nitrogen in dairy ewes. J. Dairy Sci. 81:499-508.

Dønnem, I., Å. T. Randby, and M. Eknæs. 2011. Effects of grass silage harvesting time and level of concentrate supplementation on nutrient digestibility and dairy goat performance. Anim. Feed Sci. Technol. 163:150-160.

Faverdin, P., J. P. Dolphy, J. B. Coulon, R. Vérité, J. P. Garel, J. Rouel, and B. Marquis. 1991. Substitution of roughage by concentrates for dairy cows. Livest. Prod. Sci. 27:137-156.

Fenderson, C. L., and W. G. Bergen. 1976. Effect of excess dietary protein on feed intake and nitrogen metabolism in steers. J. Anim. Sci. 42:1323-1330.

Ferguson, J. D., D. T. Galligan, and N. Thomsen. 1994. Principal descriptors of body condition score in Holstein cows. J. Dairy Sci. $77: 2695-2703$.

Hansen, B. 1989. Determination of nitrogen as elementary N, as an alternative to Kjeldahl. Acta Agric. Scand. 39:113-118.

Harfoot, C. G., and G. P. Hazlewood. 1997. Lipid metabolism in the rumen. Pages 382-426 in The Rumen Microbial Ecosystem. P. N. Hobson and C. S. Steward, ed. Chapman \& Hall, London, UK

Hymøller, L., A. L. F. Hellwing, P. Lund, and M. R. Weisbjerg. 2014. Milk production is unaffected by replacing barley or sodium hydroxide wheat with maize cob silage in rations for dairy cows. Animal 8:738-747. http://dx.doi.org/10.1017/S1751731114000329.

van Knegsel, A. T. M., H. van den Brand, J. Dijkstra, W. M. van Straalen, H. J. W. Heetkamp, S. Tamminga, and B. Kemp. 2007. Dietary energy source in dairy cows in early lactation: Energy partitioning and milk composition. J. Dairy Sci. 90:1467-1476.

Knudsen, K. E. B., P. Åman, and B. O. Eggum. 1987. Nutritive value of Danish-grown barley varieties. J. Cereal Sci. 2:173-186.

Larsen, M. K., L. Hymøller, D. B. Brask-Pedersen, and M. R. Weisbjerg. 2012a. Milk fatty acid composition and production performance of Danish Holstein and Danish Jersey cows fed different amounts of linseed and rapeseed. J. Dairy Sci. 95:3569-3578.

Larsen, M. K., U. Kidmose, T. Kristensen, P. Beaumont, and G. Mortensen. 2012b. Chemical composition and sensory quality of bovine milk as affected by type of forage and proportion of concentrate in the feed ration. J. Sci. Food Agric. 93:93-99.

Littell, R. C., G. A. Milliken, W. W. Stroup, R. D. Wolfinger, and O. Schabenberger. 2006. SAS for Mixed Models. 2nd ed. SAS Institute Inc., Cary, NC.

MacLeod, G. K., D. G. Grieve, and I. McMillan. 1983. Performance of first lactation dairy cows fed complete rations of several rations of forage to concentrate. J. Dairy Sci. 66:1668-1674.

Madsen, J., M. R. Weisbjerg, and T. Hvelplund. 2010. Concentrate composition for automatic milking systems - Effect on milking frequency. Livest. Sci. 127:45-50.
Mertens, D. R. 2002. Gravimetric determination of amylase-treated neutral detergent fiber in feeds with refluxing in beakers or crucibles: Collaborative study. J. AOAC Int. 85:1217-1240.

Nielsen, N. M., T. Kristensen, P. Nørgaard, and H. H. Hansen. 2003. The effect of low protein supplementation to dairy cows grazing clover grass during half of the day. Livest. Prod. Sci. 81:293-306.

NorFor. 2011. NorFor-The Nordic Feed Evaluation System. H. Volden, ed. EAAP Publication No. 130. Wageningen Academic Publishers, Wageningen, the Netherlands.

Oldham, J. D. 1984. Protein-energy interrelationships in dairy cows. J. Dairy Sci. 67:1090-1114.

Oltner, R., and H. Wiktorsson. 1983. Urea concentrations in milk and blood as influenced by feeding varying amounts of protein and energy to dairy cows. Livest. Prod. Sci. 10:457-467.

Randby, A. T., M. R. Weisbjerg, P. Nørgaard, and B. Heringstad. 2012. Early lactation feed intake and milk yield responses of dairy cows offered grass silages harvested at early maturity stages. J. Dairy Sci. 95:304-317.

Schoorl, N. 1929. Suiker-Titratie (Sugar titration). Chem. Weekbl. $26: 130-134$.

Sjaunja, L. O., L. Baevre, L. Junkkarinen, J. Pedersen, and J. Setälä 1991. A Nordic proposal for an energy corrected milk (ECM) formula. Pages 156-157 in Recording of Animals - State of the Art 1990. EAAP Publ. 50. Performance Centre for Agricultural Publishing and Documentation (PUDOC), Wageningen, the Netherlands.

Spahr, S. L., R. D. Shanks, G. C. McCoy, E. Maltz, and O. Kroll 1993. Lactation potential as a criterion for strategy of feeding total mixed rations. J. Dairy Sci. 76:2723-2735.

Spek, J. W., J. Dijkstra, G. van Duinkerken, and A. Bannink. 2013. A review of factors affecting milk urea concentration and its relationship with urinary urea excretion in lactating dairy cows. J. Agric. Sci. 151:407-423.

Stoldt, W. 1952. Vorslag zur Vereinheitlichung der Fettbestimmung in Lebensmitteln (Suggestion to standardize the determination of fat content in foods). Fette Seifen 54:206-207.

Thorup, V. M., S. Højsgaard, M. R. Weisbjerg, and N. C. Friggens. 2013. Energy balance of individual can be estimated in real-time on farm using frequent liveweight measures even in the absence of body condition score. Animal 7:1631-1639.

Weisbjerg, M. R., and T. Hvelplund. 1993. Estimation of net energy content (FU) in feeds for cattle. Report no. 3. National Institute of Animal Science, Copenhagen, Denmark.

Weisbjerg, M. R., L. Wiking, N. B. Kristensen, and P. Lund. 2008. Effects of supplemental dietary fatty acids on milk yield and fatty acid composition in high and medium yielding cows. J. Dairy Res. $75: 142-152$. 